Prepared in cooperation with the University of Arizona, Department of Chemical and Environmental Engineering, AECOM Technology Corporation, and the Water Environment Research Foundation

\title{
Pharmaceuticals, Hormones, Anthropogenic Waste Indicators, and Total Estrogenicity in Liquid and Solid Samples from Municipal Sludge Stabilization and Dewatering
}

Open-File Report 2011-1132 


\section{Pharmaceuticals, Hormones, Anthropogenic Waste Indicators, and Total Estrogenicity in Liquid and Solid Samples from Municipal Sludge Stabilization and Dewatering}

By Edward T. Furlong, James L. Gray, David M. Quanrud, Sondra S. Teske, Stephen L. Werner, Kathleen Esposito, Jeremy Marine, Wendell P. Ela, Steven D. Zaugg, Patrick J. Phillips, and Beverley Stinson

Prepared in cooperation with the University of Arizona, Department of Chemical and Environmental Engineering, AECOM Technology Corporation, and the Water Environment Research Foundation

Open-File Report 2011-1132 


\title{
U.S. Department of the Interior \\ KEN SALAZAR, Secretary \\ U.S. Geological Survey \\ Marcia K. McNutt, Director
}

\author{
U.S. Geological Survey, Reston, Virginia: 2012
}

For more information on the USGS - the Federal source for science about the Earth, its natural and living resources, natural hazards, and the environment, visit http://www.usgs.gov or call 1-888-ASK-USGS

For an overview of USGS information products, including maps, imagery, and publications, visit http://www.usgs.gov/pubprod

To order this and other USGS information products, visit http://store.usgs.gov

Any use of trade, product, or firm names is for descriptive purposes only and does not imply endorsement by the U.S. Government.

Although this report is in the public domain, permission must be secured from the individual copyright owners to reproduce any copyrighted materials contained within this report.

Suggested citation:

Furlong, E.T., Gray, J.L., Quanrud, D.M., Teske, S.S., Werner, S.L., Esposito, Kathleen, Marine, Jeremy, Ela, W.P., Zaugg, S.D., Phillips, P.J., and Stinson, Beverley, 2012, Pharmaceuticals, hormones, anthropogenic waste indicators, and total estrogenicity in liquid and solid samples from municipal sludge stabilization and dewatering: U.S. Geological Survey Open-File Report 2011-1132, 8 p. 


\section{Contents}

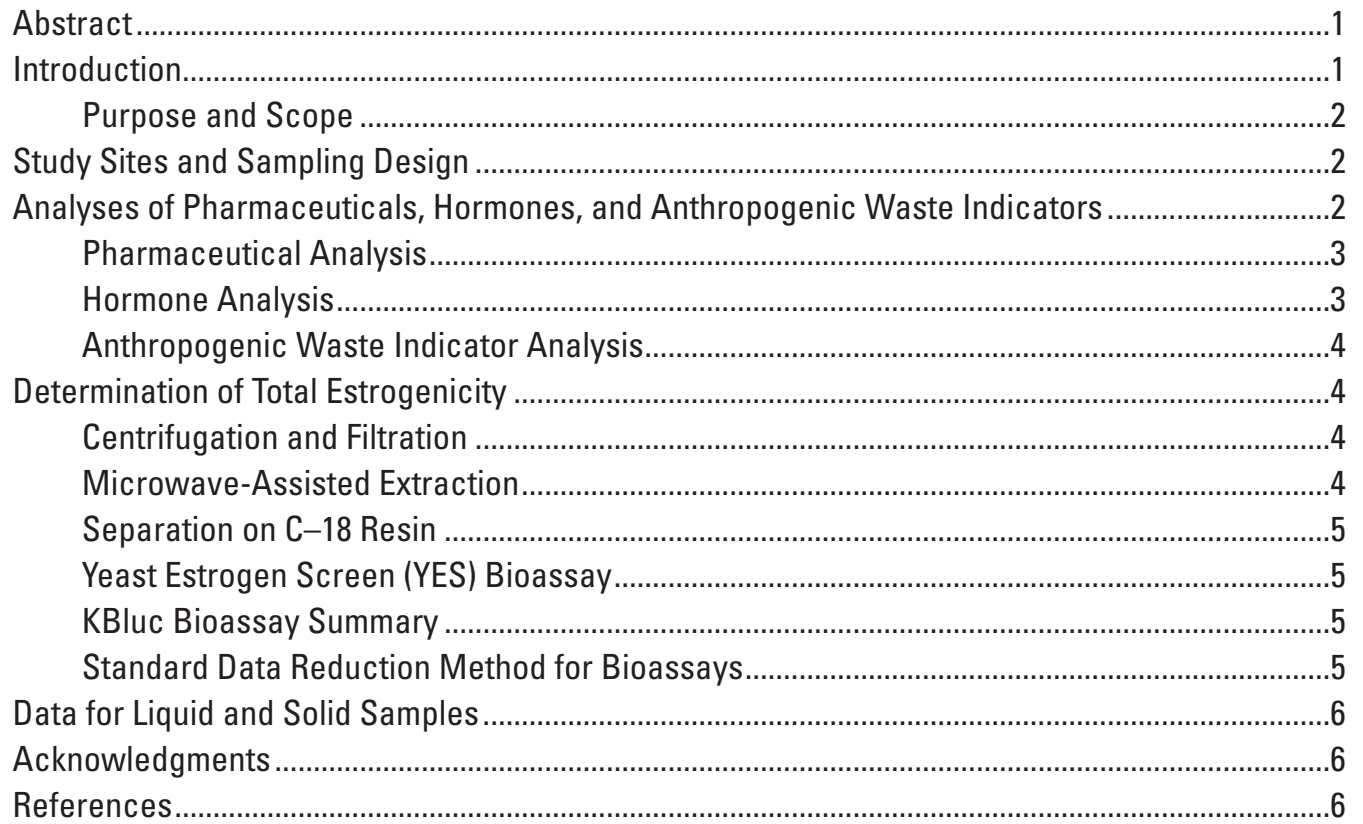

\section{Tables}

[Click on table title to view in Excel format]

1. Compound name, typical use, Chemical Abstracts Service registry number, lowest reporting level, and National Water Quality Laboratory schedule or laboratory code used for samples determined at the NWQL during this study

2. Concentrations of estrogens, androgens, progestins, and other related compounds in liquid and solid samples from Wastewater Treatment Plant A, collected between March 2006 and January 2007

3. Concentrations of estrogens, androgens, progestins, and other related compounds in liquid and solid samples from Wastewater Treatment Plant B, collected between December 2005 and May 2007

4. Concentrations of estrogens, androgens, progestins, and other related compounds in liquid and solid samples from Wastewater Treatment Plant C, collected between December 2005 and July 2006

5. Concentrations of estrogens, androgens, progestins, and other related compounds in liquid and solid samples from Wastewater Treatment Plant D, collected between March 2006 and December 2006

6. Concentrations of anthropogenic waste indicators (AWIs) in liquid and solid samples from Wastewater Treatment Plant A, collected between March 2006 and January 2007

7. Concentrations of anthropogenic waste indicators (AWIs) in liquid and solid samples from Wastewater Treatment Plant B, collected between December 2005 and January 2007

8. Concentrations of anthropogenic waste indicators (AWIs) in liquid and solid samples from Wastewater Treatment Plant C, collected between December 2005 and July 2006

9. Concentrations of anthropogenic waste indicators (AWIs) in liquid and solid samples from Wastewater Treatment Plant D, collected between March 2006 and December 2006 
10. Estrogenicity of liquid and solid samples from Wastewater Treatment Plant A, collected between March 2006 and January 2007

11. Estrogenicity of liquid and solid samples from Wastewater Treatment Plant B, collected between December 2005 and January 2007

12. Estrogenicity of liquid and solid samples from Wastewater Treatment Plant C, collected between December 2005 and July 2006

13. Estrogenicity of liquid and solid samples from Wastewater Treatment Plant D, collected between March 2006 and December 2006

14. Estrogenicity of liquid and solid samples from Wastewater Treatment Plant D, collected June 2006

15. Concentrations of pharmaceuticals in liquid and solid samples from Wastewater Treatment Plant A, collected between March 2006 and January 2007

16. Concentrations of pharmaceuticals in liquid and solid samples from Wastewater Treatment Plant B, collected between December 2005 and January 2007

17. Concentrations of pharmaceuticals in liquid and solid samples from Wastewater Treatment Plant C, collected between December 2005 and July 2006

18. Concentrations of pharmaceuticals in liquid and solid samples from Wastewater Treatment Plant D, collected between March 2006 and December 2006

\section{Conversion Factors}

\begin{tabular}{|c|c|c|}
\hline Multiply & By & To obtain \\
\hline \multicolumn{3}{|c|}{ Length } \\
\hline centimeter $(\mathrm{cm})$ & 0.3937 & inch (in.) \\
\hline millimeter (mm) & 0.03937 & inch (in.) \\
\hline meter $(\mathrm{m})$ & 3.281 & foot $(\mathrm{ft})$ \\
\hline meter $(\mathrm{m})$ & 1.094 & yard (yd) \\
\hline \multicolumn{3}{|c|}{ Volume } \\
\hline liter (L) & 33.82 & ounce, fluid (fl. oz) \\
\hline liter (L) & 2.113 & pint $(p t)$ \\
\hline liter (L) & 1.057 & quart $(\mathrm{qt})$ \\
\hline liter (L) & 0.2642 & gallon (gal) \\
\hline liter (L) & 61.02 & cubic inch $\left(\mathrm{in}^{3}\right)$ \\
\hline \multicolumn{3}{|c|}{ Mass } \\
\hline $\operatorname{gram}(\mathrm{g})$ & 0.03527 & ounce, avoirdupois (oz) \\
\hline kilogram (kg) & 2.205 & pound, avoirdupois (lb) \\
\hline \multicolumn{3}{|c|}{ Pressure } \\
\hline kilopascal (kPa) & 0.009869 & atmosphere, standard (atm) \\
\hline kilopascal (kPa) & 0.01 & bar \\
\hline kilopascal (kPa) & 20.88 & pound per square foot $\left(\mathrm{lb} / \mathrm{ft}^{2}\right)$ \\
\hline kilopascal $(\mathrm{kPa})$ & 0.1450 & pound per square inch $\left(\mathrm{lb} / \mathrm{in}^{2}\right)$ \\
\hline \multicolumn{3}{|c|}{ Density } \\
\hline kilogram per cubic meter $\left(\mathrm{kg} / \mathrm{m}^{3}\right)$ & 0.06242 & pound per cubic foot $\left(\mathrm{lb} / \mathrm{ft}^{3}\right)$ \\
\hline gram per cubic centimeter $\left(\mathrm{g} / \mathrm{cm}^{3}\right)$ & 62.4220 & pound per cubic foot $\left(\mathrm{lb} / \mathrm{ft}^{3}\right)$ \\
\hline
\end{tabular}

Temperature in degrees Celsius $\left({ }^{\circ} \mathrm{C}\right)$ may be converted to degrees Fahrenheit $\left({ }^{\circ} \mathrm{F}\right)$ as follows: ${ }^{\circ} \mathrm{F}=\left(1.8 x^{\circ} \mathrm{C}\right)+32$

Temperature in degrees Fahrenheit $\left({ }^{\circ} \mathrm{F}\right)$ may be converted to degrees Celsius $\left({ }^{\circ} \mathrm{C}\right)$ as follows: ${ }^{\circ} \mathrm{C}=\left({ }^{\circ} \mathrm{F}-32\right) / 1.8$ 


\section{Acronyms and Abbreviations}

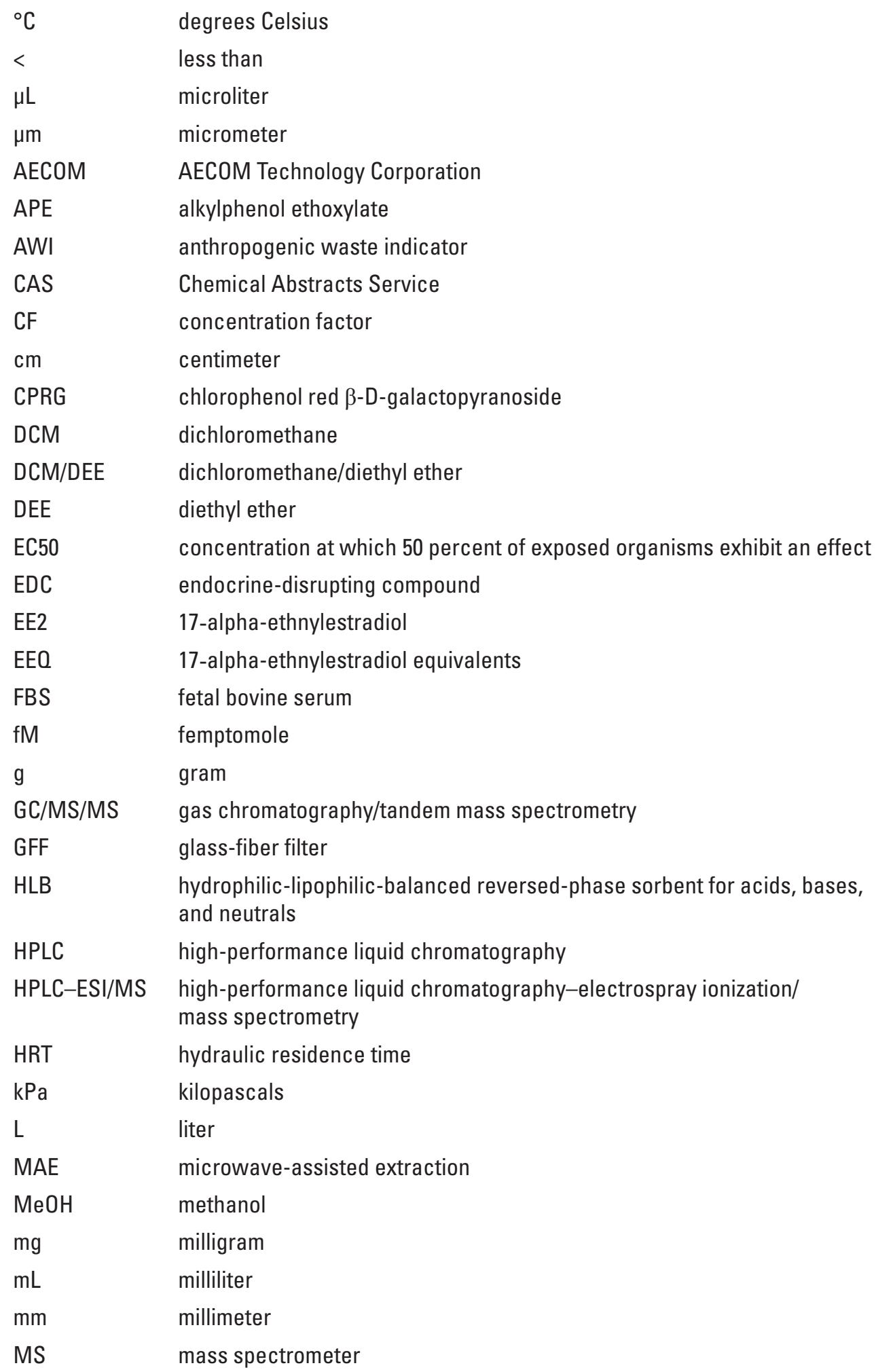




\section{Acronyms and Abbreviations-Continued}

$\begin{array}{ll}\text { MSTFA } & \text { N-methyl-N-(trimethylsilyl)trifluoroacetamide } \\ \text { ND } & \text { not detected } \\ \text { nM } & \text { nanomole } \\ \text { nm } & \text { nanometer } \\ \text { NP } & \text { nonylphenol } \\ \text { NPEO } & \text { nonylphenol ethoxylate } \\ \text { RCF } & \text { relative centrifugal force } \\ \text { RLU } & \text { relative light units } \\ \text { SPE } & \text { solid-phase extraction } \\ \text { SRT } & \text { solids-retention time } \\ \text { TMS } & \text { trimethylsilyl } \\ \text { TOC } & \text { trace organic compound } \\ \text { USGS } & \text { U.S. Geological Survey } \\ \text { V/v } & \text { volume to volume } \\ \text { WERF } & \text { Water Environment Research Foundation } \\ \text { WWTP } & \text { wastewater treatment plant } \\ \text { YES } & \text { yeast estrogen screen }\end{array}$




\title{
Pharmaceuticals, Hormones, Anthropogenic Waste Indicators, and Total Estrogenicity in Liquid and Solid Samples from Municipal Sludge Stabilization and Dewatering
}

\author{
By Edward T. Furlong, James L. Gray, David M. Quanrud, Sondra S. Teske, Stephen L. Werner, Kathleen Esposito, \\ Jeremy Marine, Wendell P. Ela, Steven D. Zaugg, Patrick J. Phillips, and Beverley Stinson
}

\section{Abstract}

The ubiquitous presence of pharmaceuticals and other emerging contaminants, or trace organic compounds, in surface water has resulted in research and monitoring efforts to identify contaminant sources to surface waters and to better understand loadings from these sources. Wastewater treatment plant (WWTP) discharges have been identified as an important point source of trace organic compounds to surface water and understanding the transport and transformation of these contaminants through wastewater treatment processes is essential to controlling their introduction to receiving waters.

Whereas the effects of many trace organic compounds are not well known, a number are classified as endocrinedisrupting compounds, including natural and synthetic estrogens, bisphenol A, alkylphenol ethoxylates, particularly nonylphenol ethoxylates, and nonylphenol. This report documents the results from measurements of individual endocrinedisrupting compounds, other trace organic compounds, and yeast estrogen screen (YES) bioassay estimates of estrogenic activity from a multiple-year, multiple-WWTP study. This work was undertaken by scientists of the U.S. Geological Survey, the University of Arizona, and AECOM Technology Corporation (AECOM) in cooperation with the Water Environment Research Foundation (WERF). The purpose of the study was to characterize the reduction of estrogenicity and endocrine-disrupting compounds (EDCs) through wastewater treatment processes typical of WWTPs in the United States, with emphasis on the solids phase. In this study, four WWTPs were sampled two to four times annually between December 2005 and January 2007. Synoptic liquid samples of primary influent, primary effluent, and secondary (treated) effluent were collected, and where appropriate, solid samples also were collected. Field and laboratory quality-assurance/ quality-control samples also were analyzed in this study. The results from this study are published as a U.S. Geological Survey Open-File Report to ensure adequate documentation of the original results, provide a single citable source of original results for subsequent interpretive reports, and ensure continued public access to these results through online publication.

\section{Introduction}

The common occurrence of pharmaceuticals and other emerging contaminants, also referred to as trace organic compounds (TOCs), in surface water (Kolpin and others, 2002; Glassmeyer and others, 2007) has resulted in research and monitoring efforts to identify TOC sources to surface waters and to understand the loadings of TOCs from these sources. Wastewater treatment plant (WWTP) discharges have been identified as an important point source of TOCs to surface water (Carballa and others, 2007; Dickenson and others, 2009; Joss and others, 2004, 2005; Wick and others, 2009), and understanding the transport and transformation of TOCs through wastewater treatment processes is essential to controlling the introduction of TOCs to surface-water environments.

Whereas the effects of many TOCs are unknown, a number are classified as endocrine-disrupting compounds (EDCs); specific examples include natural and synthetic estrogens, bisphenol A, alkylphenol ethoxylates (APEs), particularly nonylphenol ethoxylates (NPEOs), and nonylphenol (NP), a persistent transformation product of NPEOs (Jobling and Sumpter, 1993; Länge and others, 2001). Endocrine disruption in surface-water environments is evidenced at biochemical, cellular, organismal, and ecological levels of organization. Commonly observed endpoints include inappropriate production of vitellogenin, a female egg yolk protein, by males and juveniles, the observation of ova in testicular tissue, the induction of female secondary sexual characteristics in putatively male fish, and skewed sex ratios in both wild and laboratory populations. These effects have been identified in surfacewater environments in North America and Europe and are associated with WWTP discharges (Vajda and others, 2008; Woodling and others, 2006).

Whereas public and scientific interest in the presence and effects of EDCs is substantial, the analytical techniques necessary to determine the compositions and concentrations of the diverse, heterogeneous suite of EDCs can be complex and costly. Bioassay techniques that quantify estrogenic receptor response can be a cost-effective means of characterizing the estrogenicity both of liquid and solid samples if the relation between individual EDC constituents and bioassay estrogenic response can be established qualitatively and quantitatively. 


\section{Purpose and Scope}

This report documents the results from measurements of individual EDC and TOC chemicals and yeast estrogen screen (YES) bioassays from a multiple-year, multiple-WWTP study undertaken by scientists of the U.S. Geological Survey (USGS), the University of Arizona, and AECOM Technology Corporation (AECOM) in cooperation with the Water Environment Research Foundation (WERF). All data tables are presented in Microsoft $\mathrm{f}^{\circledR}$ Excel format and can be accessed through links at their first citation within this report. The purpose of the study was to characterize the reduction of estrogenicity and EDCs through wastewater treatment processes typical of WWTPs in the United States, with emphasis on the solids phase. Analysis of solid-phase samples was of particular importance as the understanding of TOCs in wastewater and environmental solid phases is not well documented.

In this study, four WWTPs were sampled two to four times annually between December 2005 and January 2007. Synoptic liquid samples of primary influent, primary effluent, and secondary (treated) effluent were collected based on the typical hydraulic residence time (HRT) of each WWTP, as determined by WWTP operations staff. Where appropriate, solid samples also were collected on a schedule based on the typical HRT of each WWTP. However, due to the long solidsretention times (SRTs) of many solids-treatment unit processes (for example, digestion), synoptic sampling was not possible. However, the long SRTs also result in concentrations that are less variable over time than for liquid samples, so comparisons between sequential unit processes are valid. Upon receipt by participating laboratories, solid and liquid samples were split; one set of samples was analyzed by chemical methods to determine a suite of individual pharmaceuticals, 17 hormones (estrogens, androgens, and progestins), and a suite of anthropogenic waste indicator (AWI) compounds. Many of the hormones and AWIs are known or suspected EDCs. The second set of split samples was assessed for total estrogenicity, quantified as ethinyl estradiol equivalents (EEQ) by using the YES bioassay. Field and laboratory quality-assurance/qualitycontrol samples also were analyzed in this study and the results met acceptance criteria for each method.

Solid and liquid samples from WWTPs are complex samples typically containing many organic and inorganic interferences that were expected to make sample analysis difficult. Also, at the time of this study, many of the methods were not approved as official methods of the USGS and were classified instead as research or custom methods. Data from unapproved methods cannot be entered into the USGS National Water Information System (Miller, 2004), the standard, publicly accessible data repository for results from official USGS methods. Thus, the results from this study were aggregated into this USGS Open-File Report to (1) ensure adequate documentation of the original results, (2) provide a clear description of the analytical methods used to produce these results,
(3) provide a single citable source of original results for subsequent interpretive reports, and (4) ensure continued public access to the results through online publication as a USGS Open-File Report.

\section{Study Sites and Sampling Design}

Four WWTPs were sampled as a part of this study. The four WWTPs are hereinafter referred to as Plants A, B, C, or D in all tables of results. To encourage participation and cooperation for the extensive sample collection this study required, WWTPs are not identified by location. All four plants are secondary treatment plants, with screening, primary treatment (settling), followed by secondary treatment with activated sludge, prior to disinfection and discharge. Solids handling steps varied among plants and included thickening by gravity, gravity belt, and dissolved air flotation; stabilization using lime addition, aerobic digestion, and anaerobic digestion; chemical conditioning; dewatering by centrifugation; and other processes including composting and pelletization.

Samples were collected from the WWTPs approximately every 3 or 6 months during 1 year. Aqueous samples and some high water-content solid samples were collected based on the average HRT of each plant, which was provided by the operations staff of each plant. The purpose of adjusting sampling time to HRT was to maximize comparability among different unit processes when estimating loads of TOCs. Sample collection was conducted according to USGS water-quality trace-organic compound sample-collection protocols (U.S. Geological Survey, variously dated), adapted for the specific circumstances present in WWTPs. After an initial training period by USGS scientists, AECOM and participating WWTP staff assisted the USGS with sample collection. After collection, samples were stored on ice in insulating coolers and shipped by overnight express to the USGS and University of Arizona laboratories for TOC and bioassay analyses, respectively.

\section{Analyses of Pharmaceuticals, Hormones, and Anthropogenic Waste Indicators}

Three separate trace organic chemical analyses were done on separate subsamples of liquid and solid samples. The three classes of chemicals measured by each analysis were (1) pharmaceuticals; (2) hormones, which included estrogens, androgens, progestins, and the fecal sterols cholesterol and coprostanol; and (3) anthropogenic waste indicators (AWIs), which included the estrogenic APEs, bisphenol A, NPEOs, and NP. Table 1 lists the chemical name, Chemical Abstracts Service (CAS) number, and typical use of each chemical. 


\section{Pharmaceutical Analysis}

Pharmaceuticals were determined in liquid samples by using the procedure of Cahill and others (2004). In this method, the target pharmaceuticals and an added performance surrogate first were removed from filtered 1-liter (L) water samples by passing the water through an Oasis ${ }^{\circledR}$ hydrophiliclipophilic balanced reversed-phase sorbent for acids, bases, and neutrals (HLB) solid-phase extraction (SPE) cartridge (500-milligram [mg] bed mass; Waters Corporation, Milford, Massachusetts). The pharmaceuticals then were eluted from the SPE cartridge by using 6 milliliters $(\mathrm{mL})$ of methanol followed by $4 \mathrm{~mL}$ of methanol acidified with trifluoroacetic acid ( 0.1 percent). The two eluents were combined, concentrated to near dryness, reconstituted into formate buffer with an internal standard, and filtered. Pharmaceuticals in the concentrated extracts were separated using reversedphase, high-performance liquid chromatography (HPLC), which was interfaced with a quadrupole mass spectrometer (MS) equipped with an electrospray ionization source (HPLC-ESI/MS) for identification and quantitative analysis. The electrospray ionization source was operated in the positive-ion mode. Selected-ion monitoring MS was used to improve sensitivity and specificity. Qualitative identification was based on HPLC retention and at least two compoundspecific fragment ions for each pharmaceutical. Quantitation was by the injection internal standard method.

For solid samples, the approach of Kinney and others (2006) was used. Approximately 1 gram (g) of wet solids was weighed into an 11-mL pressurized liquid extraction vessel, an aliquot of a cocktail of performance surrogates was added, and the sample was extracted using pressurized liquid extraction (ASE 200; Dionex Corporation, Sunnyvale, California), using five static cycles $\left(10\right.$ minutes each at $130^{\circ} \mathrm{C}$ and 10,300-kilopascals [kPa]) with an acetonitrile/water mixture (70:30, volume to volume $[\mathrm{v} / \mathrm{v}])$. One $\mathrm{mL}$ of the total extract was filtered using a $0.20-\mu \mathrm{m}$ (micrometer) syringe filter into an HPLC vial, and the acetonitrile evaporated under nitrogen. The sample was reconstituted to about $0.95 \mathrm{~mL}$ using a 10-millimolar aqueous ammonium formate buffer; an aliquot of a nicotinamide- $2,4,5,6-d_{4}$ solution was added as an injection internal standard and the final volume of the extract was brought to about $1 \mathrm{~mL}$. Analysis by HPLC-ESI/MS followed the procedure of Cahill and others (2004) outlined in the preceding paragraph.

\section{Hormone Analysis}

Estrogens, androgens, progestins, and fecal sterols were determined in whole-water (liquid + solids) samples using C-18 SPE followed by isotope-dilution capillary gas chromatography/tandem mass spectrometry (GC/MS/MS). Briefly, 1-L whole-water samples were poured into stainlesssteel extraction tubes equipped with a multigrade glass-fiber filter (GFF) over a 47-millimeter (mm) C-18 SPE (Supelco ENVI+; Sigma-Aldrich Corporation, St. Louis, Missouri) disk. The samples were passed through the $\mathrm{GFF} / \mathrm{C}-18$ disk under pressure, as needed. Just prior to extraction, an aliquot of a cocktail of 12 stable-isotope-labeled analogues of estrogens, androgens, progestins, and fecal sterols was added to each sample to quantify the hormones by the stable isotope dilution method (De Hoffman and others, 1996). Following compound isolation, the $\mathrm{GFF} / \mathrm{C}-18$ disk was rinsed with 25 percent methanol $(\mathrm{MeOH})$ in water, dried with nitrogen, and the compounds eluted with $\mathrm{MeOH}$. The $\mathrm{MeOH}$ eluent was evaporated to dryness and reconstituted in a mixture of 20 percent diethyl ether in dichloromethane (DCM/DEE). The extract was then passed through a 1-g Florisil SPE column and eluted with an additional aliquot of the DCM/DEE solution. The eluent was reduced in volume with nitrogen, quantitatively transferred to a 5-mL reaction vial, and evaporated to dryness. Ketone and alcohol groups on the analytes and isotopically labeled surrogates were derivatized to trimethylsilyl (TMS)-substituted analogs to make them stable for separation by gas chromatography. Derivatization was accomplished using N-methyl$\mathrm{N}$-(trimethylsilyl)trifluoroacetamide (MSTFA) activated with 2-(trimethylsilyl)ethanethiol. The analytes were separated by capillary gas chromatography and quantified by tandem quadrupole mass spectrometry using an isotope dilution procedure.

For solid samples, the derivatization, chromatographic separation, and mass spectrometric quantitation steps used for water samples remained the same, whereas sample extraction and isolation steps were substantially different. ${ }^{1}$ Wet solids were loaded into a 33-mL stainless-steel extraction vessel. Approximately $1 \mathrm{~g}$ of solid material (on a dry mass basis) was used. Any remaining cell volume was filled with ashed quartz sand. Just prior to extraction, an aliquot of a cocktail of 12 stable-isotope-labeled analogues of estrogens, androgens, progestins, and fecal sterols was added to each sample to quantify the hormones by the stable-isotope dilution method (De Hoffman and others, 1996). The wet sample was then extracted using an automated pressurized liquid extraction system (ASE 200; Dionex Corp., Sunnyvale, California), using a programmed multiple-cycle extraction procedure. In the procedure, the samples are extracted three times using a mixture of water:isopropyl alcohol $(50: 50, \mathrm{v} / \mathrm{v})$ at $120^{\circ} \mathrm{C}$ and then extracted three times with water:isopropyl alcohol (20:80, $\mathrm{v} / \mathrm{v})$ at $200^{\circ} \mathrm{C}$. The entire extraction sequence is carried out at a pressure of $13.8 \times 10^{3} \mathrm{kPa}$.

\footnotetext{
${ }^{1}$ Subsequent to this study, some changes were made to the hormone analysis procedures that could result in unknown data bias. Specifically, for both water and sediment methods, a few different isotopically labeled compounds were added and others subtracted to address intermittent performance issues not apparent during this study. Also, Florisil elution solvent was changed from 80 percent $\mathrm{DCM} / 20$ percent $\mathrm{DEE}$ to 95 percent $\mathrm{DCM} / 5$ percent $\mathrm{MeOH}$ (waters) or 90 percent DCM/10 percent $\mathrm{MeOH}$ (solids) to improve polar compound recovery, address safety concerns associated with formation of peroxides in oxygen-exposed DEE, and to address intermittent losses of phenolic compounds due to reaction with peroxides not apparent in this study.
} 
The extraction aliquots were automatically transferred by nitrogen pressure to a glass vessel sealed with a Teflonfaced silicone septum. The three extraction aliquots processed at $120^{\circ} \mathrm{C}$ were automatically combined in a single glass vessel. The three extract aliquots processed at $200^{\circ} \mathrm{C}$ were automatically combined in a separate sealed glass vessel. The $200^{\circ} \mathrm{C}$ extract was passed through an SPE cartridge (Oasis ${ }^{\circledR}$ HLB, 500-mg bed mass; Waters Corporation, Milford, Massachusetts), followed by the $120^{\circ} \mathrm{C}$ extract. The Oasis ${ }^{\circledR}$ cartridge was dried with nitrogen, connected to a second cartridge containing $1.5 \mathrm{~g}$ anhydrous sodium sulfate over $2 \mathrm{~g}$ of Florisil bed mass, and the hormones were eluted and purified in a single step with three successive $10-\mathrm{mL}$ aliquots of DCM/DEE (80:20, v/v). The combined DCM/DEE aliquots were reduced under nitrogen to dryness. The dried sample was then derivatized, separated, and quantified as described for the whole-water samples.

\section{Anthropogenic Waste Indicator Analysis}

The AWIs, which included the nonhormonal, synthetic organic EDCs, were determined in filtered liquid samples by the method of Zaugg and others (2007). Briefly, liquid samples were filtered through a $0.7-\mu \mathrm{m}$ ashed glass-fiber filter, and approximately $1 \mathrm{~L}$ of filtered sample was passed through an Oasis ${ }^{\circledR}$ HLB SPE cartridge under negative pressure. Just prior to isolation by SPE, an aliquot of a cocktail of surrogate compounds was added to the sample. The recovery of these surrogates was determined as part of the analysis to assess method performance.

The SPE cartridge was dried with nitrogen and the AWIs were then eluted with two successive aliquots of DCM/DEE $(4: 1, \mathrm{v} / \mathrm{v})$. The first $15-\mathrm{mL}$ aliquot is used to rinse the sample bottle prior to elution through the SPE cartridge to extract any AWIs adsorbed to the bottle surface. The second 3-mL elution is applied directly to the SPE cartridge to elute any AWIs remaining on the cartridge. A final elution with $3 \mathrm{~mL}$ of DEE is then applied to the SPE cartridge to maximize compound recovery. An aliquot of an injection internal standard cocktail of perdeuterated polycyclic aromatic hydrocarbons was added to the combined eluent fractions of each sample, and the sample extract was reduced to $0.4 \mathrm{~mL}$ final volume. The sample final extract was analyzed for the 67 AWI compounds by capillary gas chromatography coupled to a quadrupole mass spectrometer operated under full-scan, electron-impact ionization conditions. Sample AWI detections were verified by comparison to an in-house mass spectral library developed from analysis of authentic standards. Multiple-point calibration using the injection internal standard method was used to determine sample concentrations for each compound.

The AWIs were determined in solid samples by using the method of Burkhardt and others (2006). The extraction procedure is identical to the hormone extraction procedure except as noted. Just prior to extraction, an aliquot of a cocktail of surrogates was added to each sample; the surrogates were quantified as part of the analysis to evaluate method performance. After extraction, the combined DCM/DEE aliquots were reduced under nitrogen to between 2 and $4 \mathrm{~mL}$, an aliquot of an injection internal standard cocktail of perdeuterated polycyclic aromatic hydrocarbons was added, and the sample extract was reduced to a volume of $1 \mathrm{~mL}$. The sample final extract was analyzed for the 67 AWI compounds by capillary gas chromatography coupled to a quadrupole mass spectrometer operated under full-scan, electron-impact ionization conditions. Sample AWI detections were verified by comparison to an in-house mass spectral library developed from analysis of authentic standards. Multiple-point calibration using the injection internal standard method was used to determine sample concentrations for each compound.

Compounds that were not detected were typically reported as "less than" values; that is, " $<20 \mu \mathrm{g} / \mathrm{L}$ " for liquid samples and "ND" for solid samples. These values are based on the reporting level of the method. The reporting level is provided as a concentration that is based upon a standard sample size. For liquid samples in this study, the standard sample size is one liter. Standard solid sample sizes varied: for hormones the standard sample size used to determine reporting levels was $0.2 \mathrm{~g}$ dry mass, for AWIs $25 \mathrm{~g}$ dry mass, and for pharmaceuticals $35 \mathrm{~g}$ dry mass. If the dry mass of the sample is less than the standard dry mass for the analysis, the reporting levels are raised to reflect the lower dry mass of sample analyzed.

\section{Determination of Total Estrogenicity}

\section{Centrifugation and Filtration}

Liquid-phase samples (raw influent, primary clarifier effluent, secondary clarifier effluent, effluent from dewatering of thickened sludge, and liquid from the dewatering process after anaerobic digestion [centrate]) were separated into liquid and solid fractions using a Beckman J-10 centrifuge (Beckman Coulter, Incorporated, Brea, California) with a JA-10 rotor (20 minutes, relative centrifugal force $[R C F]=17,000$ ). Liquid portions were decanted and filtered using $3.1-\mu \mathrm{m}$ and $0.7-\mu \mathrm{m}$ Pall glass-fiber filters (Pall Corporation, Port Washington, New York).

The liquid and solid fraction of each sample was analyzed for estrogenic activity. Solid-phase samples (sludges/biosolids) were separated using centrifugation and the solid fractions were analyzed. Liquid centrates were not tested because it was assumed that the EDCs of interest, which typically are hydrophobic, would be found in the solid fraction.

\section{Microwave-Assisted Extraction}

After centrifugation/filtration, all solid samples (sludges/ biosolids) were extracted in methanol using a microwaveassisted extraction (MAE) procedure. About $1 \mathrm{~g}$ (dry weight) of solid was suspended in $20 \mathrm{~mL}$ of methanol and extracted at constant pressure (138 $\mathrm{kPa}$ for 30 minutes) using a CEM-MDS 2100 Microwave Digestion System (CEM Corporation, Matthews, North Carolina). Reactor contents were cooled for 45 minutes inside the microwave unit before liquids were decanted into ashed glass vials. Methanol extracts were evaporated to $1 \mathrm{~mL}$ under nitrogen gas. 


\section{Separation on C-18 Resin}

Solid-phase microwave extracts were diluted to 1-percent methanol (v/v) in Nanopure water (Nanopure Infinity, Barnstead Thermolyne, Dubuque, Iowa) water and passed through reversephase (C-18 octadecyl) resin disk (Empore, 3M Purification, Incorporated, Eagan, Minnesota). The 47-mm C-18 disks were preconditioned with two $10-\mathrm{mL}$ volumes of 100 percent ethyl alcohol (Pharmco-AAPER, a subsidiary of Greenfield Ethanol, Chatham, Ontario, Canada) and $10 \mathrm{~mL}$ of Nanopure water as prescribed by the resin manufacturer. Retained organics were sequentially eluted off $\mathrm{C}-18$ disks using $10 \mathrm{~mL}$ of a 20-percent methanol in water solution, followed by $10 \mathrm{~mL}$ of a 50 -percent methanol in water solution, and then $10 \mathrm{~mL}$ of an 80 -percent methanol in water solution.

For liquid-phase $0.7-\mu \mathrm{m}$ filtrates, whole samples (undiluted) were applied and sequentially eluted (as described above) from $\mathrm{C}-18$ disks. Eluates were dried under nitrogen gas and redissolved in autoclaved Nanopure water to yield final concentration factors of 200-500 for estrogenic activity analysis. Solid-phase eluates were similarly dried under nitrogen gas, resuspended with 1-2 $\mathrm{mL}$ of autoclaved Nanopure water, then filtered through a $0.7-\mu \mathrm{m}$ glass-fiber filter prior to analysis.

\section{Yeast Estrogen Screen (YES) Bioassay}

Total estrogenic activity was measured using the YES bioassay of Routledge and Sumpter (1996) as amended by DeBoever and others (2001). The Saccharomyces cerevisiae strain was provided by John Sumpter of Brunel University, Oxbridge, U.K. The YES is a yeast-based in vitro bioassay utilizing a human estrogen receptor recombinant engineered with a beta-galactosidase reporter gene (lacZ) downstream from the estrogen response element. Resultant total estrogenic activity is expressed as an equivalent concentration of a known estrogenic compound-here, 17-alpha-ethnylestradiol (EE2), an oral contraceptive.

Each sample concentrate was serially diluted across 10 wells of a 96-well micro-titer plate (Corning, Incorporated, Lowell, Massachusetts). Each dilution series was initiated by placing 100 microliters $(\mu \mathrm{L})$ of sample concentrate in the first well of a single row. Fifty $\mu \mathrm{L}$ were transferred to the second column and mixed with $50 \mu \mathrm{L}$ of Nanopure water (twofold dilution per step). The process was repeated across each row to produce a maximum dilution factor of 29 . Fifty $\mu \mathrm{L}$ of Nanopure water that was pretreated by passage through the $\mathrm{C}-18$ resin were added to wells 11 and 12 of each row to serve as (negative) process controls. The eight rows of each 96-well plate provided replicate data $(\mathrm{n}=8)$ for estimation of experimental error. A standard series was developed in a similar manner with each set of measurements using concentrations of EE2 from $1.0 \times 10^{-7}$ to $5.0 \times 10^{-12}$ molar.

Yeast cells were grown in the Routledge/Sumpter medium to an absorbance (A630) of $1.0 \mathrm{~cm}^{-1}$. The culture was then diluted in the same medium to an absorbance (A630) of $0.133 \mathrm{~cm}^{-1}$, and $150 \mu \mathrm{L}$ of the diluted suspension was added to each well of the 96 -well plate (total volume $200 \mu \mathrm{L}$ per well). The resultant A630 value in each well was then about $0.10 \mathrm{~cm}^{-1}$. Plates were incubated for 24 hours at $32^{\circ} \mathrm{C}$ for growth of $S$. cerevisiae and estrogen-dependent expression of lacZ. At that point, $50 \mu \mathrm{L}$ of cycloheximide/CPRG (chlorophenol red $\beta$-D-galactopyranoside) solution consisting of $3 \mathrm{~mL}$ of autoclaved Nanopure water, $2 \mathrm{~mL}$ of $10 \mathrm{mg} / \mathrm{mL}$ cycloheximide, and $200 \mu \mathrm{L}$ of $10 \mathrm{mg} / \mathrm{mL} \mathrm{CPRG}$ was added to each test well. Following an additional 24-hour incubation at $32^{\circ} \mathrm{C}$ for $\beta$-galactosidase-dependent color development, absorbance was measured at $570 \mathrm{~nm}$ ( $\beta$-galactosidase activity) and $630 \mathrm{~nm}$ (turbidity). The contribution of cell-dependent light scattering to A570 measurements was determined by measuring the ratio of A570/A630 (here defined as R) in the negative control wells. The $\beta$-galactosidase activity was then corrected to A570 $-\mathrm{R} \times \mathrm{A} 630$. Dose-response curves were plotted for environmental samples and the positive (EE2) control.

\section{KBluc Bioassay Summary}

Due to its high operational costs, the T47D-KBluc cell line bioassay developed by Wilson and others (2004) was used on a subset of samples as a second in vitro technique to measure estrogenic activity. Cells were maintained in RPMI-1640 Medium with 10 percent fetal bovine serum (FBS) (HyClone Laboratories, Incorporated, Logan, Utah); no antibiotics were added to the medium. The bioassay was conducted in 24-well plates, and wells were rinsed with estrogen-free medium containing 3 percent charcoal dextran-treated FBS (Atlanta Biologicals, Incorporated, Lawrenceville, Georgia). Samples were serially diluted in triplicate across plates in estrogenfree growth medium, and 50,000 T47D cells were seeded per well. Plates were incubated in 5 percent carbon dioxide for 48 hours at $35^{\circ} \mathrm{C}$. Subsequently, cells were harvested using lysis buffer of which $100 \mu \mathrm{L}$ from each well of the lysed cell solution was collected and transferred to a 96-well luminometer plate. Luciferase activity was quantified using an Analyst AD Plate Reader (Molecular Devices, Sunnyvale, California). The positive estrogen control consisted of decline dilutions of EE2 (Sigma-Aldrich Corporation, St. Louis, Missouri) from 10 nanomole $(\mathrm{nM})$ to 1 femptomole (fM). Data were plotted as relative light units (RLU) relative to EE2 concentration. A negative control plate consisting of medium and cells was run concurrently with each set of environmental samples.

\section{Standard Data Reduction Method for Bioassays}

The traditional technique to quantify estrogenic activity in environmental samples relies upon identifying the midpoint (50 percent, EC50) level of response in both the environmental sample and positive control (EE2) dose response curves. In this approach, the estrogenic response of an environmental sample is converted to an equivalent concentration (EEQ) of the known estrogen concentration (EE2, used in this project) using: $\mathrm{EEQ}=\mathrm{EC} 50 \mathrm{EE} 2 /(\mathrm{EC} 50$ sample $\times \mathrm{CF})$, where EC50sample is the volume fraction of the sample producing a 
50 percent maximal response, EC50EE2 is the concentration of EE2 that produces a 50 percent maximal response in the positive control dose response curve, and $\mathrm{CF}$ is the concentration factor of the sample extract (typically 200-500 for liquid-phase samples). In this project estrogenic activity in several samples could not be determined using the traditional EC50 method due to sample toxicity inhibiting the estrogenic response. A new data reduction method was devised and was deemed the "First Response" method. The method relies upon identifying the lowest concentration of sample in the assay plate dilution series that exhibits an estrogenic response significantly above background. A statistical approach using Student's t-tests was used to determine when significant departure from baseline occurred. Using this information, the method then follows in a similar fashion to the EEQ equation above. The new method is described in Teske (2009).

\section{Data for Liquid and Solid Samples}

The analytical results from this study are contained in tables 2-18. The concentrations of hormones in liquid and solid samples are reported for plants A (table 2), B (table 3), $\mathrm{C}$ (table 4), and D (table 5). Individual hormone concentrations in liquid samples are reported in nanograms per liter, and individual hormone concentrations for solid samples are reported in micrograms per kilogram of dry solid. Similarly, AWI concentrations (including nonhormonal synthetic EDC trace organic compounds) for liquid and solid samples are reported for plants A (table 6), B (table 7), C (table 8), and D (table 9). The concentrations of individual AWIs in liquid samples are reported in micrograms per liter, and the concentrations of individual AWIs in solid samples are reported in micrograms per kilogram of dry solid. These two classes of TOCs follow each other in the table order of this report to aid comparison with the estrogenicity assay results because individual hormones and AWIs have been identified as contributors to estrogenic response in assays of environmental samples.

The YES bioassay results are reported for plants A (table 10), B (table 11), C (table 12), and D (table 13). The KBluc estrogen receptor bioassay was used for a limited set of samples from plant D and is reported in table 14. The estrogenicity results for both the YES and KBluc assays are reported as molar equivalents of EE2. The molar concentrations in tables 10 to 14 are reported in exponential notation, a standard format for this assay, in the commonly used engineering notation of X.X E-YY; that is, $9.1 \mathrm{E}-13$ moles as EE2 equivalents corresponds to $9.1 \times 10^{-13}$ moles as EE2 equivalents.

Concentrations of individual pharmaceuticals in liquid and solid samples are reported for plants A (table 15), B (table 16), C (table 17), and D (table 18). The concentrations of individual pharmaceuticals in liquid samples are reported in micrograms per liter, and the concentrations of individual pharmaceuticals in solid samples are in reported micrograms per kilogram of dry solid.
Quality-assurance/quality-control results are included in the tables for hormones, AWIs, and pharmaceuticals. Typically, surrogate recovery results are listed for each sample or replicate analysis results from two subsamples of the same sample. The surrogates are isotopically labeled versions of compounds determined in this study or are synthetic compounds not found in environmental samples. Results from these surrogates are reported as a percentage of the amount added and are used to assess method performance for each sample. Replicate sample results are in the concentration units appropriate for hormones or AWIs in solid or liquid samples. Reagent blank samples were processed with each set of environmental samples, and if blank contamination of any compound was detected, the environmental results for that sample set were censored if the concentration of the compound in the blank was greater than 5 percent of the environmental sample.

\section{Acknowledgments}

A substantial portion of the results of this study was supported by Water Environment Research Foundation (WERF) Grant 04-HHE-6 "Fate of Estrogenic Compounds during Municipal Sludge Stabilization and Dewatering." The authors of this report also gratefully acknowledge extensive support from Dana W. Kolpin, USGS Toxic Substances Hydrology Program Emerging Contaminants Project, and Daniel Edwards, New York Water Science Center, USGS, for critical assistance in training and collection of liquid samples. We also thank the technical staff of the four WWTPs sampled in this study, without whose cooperation this research could not have been completed.

\section{References}

Burkhardt, M.R., Zaugg, S.D., Smith, S.G., and ReVello, R.C., 2006, Determination of wastewater compounds in sediment and soil by pressurized solvent extraction, solid-phase extraction, and capillary-column gas chromatography/ mass spectrometry: U.S. Geological Survey Techniques and Methods, book 5, chap. B2, $40 \mathrm{p}$.

Cahill, J.D., Furlong, E.T., Burkhardt, M.R., Kolpin, D.W., and Anderson, L.G., 2004, Determination of pharmaceutical compounds in surface- and ground-water samples by solid-phase extraction and high-performance liquid chromatography/electrospray ionization mass spectrometry: Journal of Chromatography A, v. 1041, p. 171-180.

Carballa, M., Omil, F., Ternes, T., and Lema, J.T., 2007, Fate of pharmaceutical and personal care products (PPCPs) during anaerobic digestion of sewage sludge: Water Research, v. 41 , no. 10 , p. $2139-2150$. 
De Hoffman, E., Charette, J., and Stroobant, V., 1996, Mass spectrometry-Principles and applications: New York, John Wiley and Sons, p. 165-168.

Dickenson, E.R.V., Drewes, J.E., Sedlak, D.L., Wert, E.C., and Snyder, S.A., 2009, Applying surrogates and indicators to assess removal efficiency of trace organic chemicals during chemical oxidation of wastewaters: Environmental Science and Technology, v. 43, no. 16, p. 6242-6247.

Glassmeyer, S., Kolpin, D.W., Furlong, E.T., and Focazio, M.T., 2007, Environmental presence and persistence of pharmaceuticals - An overview, in Aga, D.S., ed., Fate of pharmaceuticals in the environment and in water treatment systems: Boca Raton, Fla., CRC Press, Taylor \& Francis Books, $408 \mathrm{p}$.

Jobling, S., and Sumpter, J.P., 1993, Detergent components in sewage effluent are weakly oestrogenic to fish: An in vitro study using rainbow trout (Oncorhynchus mykiss) hepatocytes: Aquatic Toxicology, v. 27, no. 3-4, p. 361-372.

Joss, A., Andersen, H., Ternes, T., Richle, P.R., and Siegrist, H., 2004, Removal of estrogens in municipal wastewater treatment under aerobic and anaerobic conditionsConsequences for plant optimization: Environmental Science and Technology, v. 38, no. 11, p. 3047-3055.

Joss, A., Keller, A.E., Alder, A.C., Göbel, A., McArdell, C.S., Ternes, T., and Siegrist, H., 2005, Removal of pharmaceuticals and fragrances in biological wastewater treatment: Water Research, v. 39, no. 14, p. 3139-3152.

Kinney, C.A., Furlong, E.T., Zaugg, S.D., Burkhardt, M.R., Werner, S.L., Cahill, J.D., and Jorgensen, G.R., 2006, Survey of organic wastewater contaminants in biosolids destined for land application: Environmental Science and Technology, v. 40, no. 23, p. 7207-7215.

Kolpin, D.W., Furlong, E.T., Meyer, M.T., Thurman, E.M., Zaugg, S.D., Barber, L.B., and Buxton, H.T., 2002, Pharmaceuticals, hormones, and other organic wastewater contaminants in US streams, 1999-2000-A national reconnaissance: Environmental Science and Technology, v. 36, no. 6, p. 1202-1211.

Länge, R., Hutchinson, T.H., Croudace, C.P., Siegmund, F., Schweinfurth, H., Hampe, P., Panter, G.H., and Sumpter, J.P., 2001, Effects of the synthetic estrogen $17 \alpha$-ethinylestradiol on the life-cycle of the fathead minnow (Pimephales promelas): Environmental Toxicology and Chemistry, v. 20, no. 6, p. 1216-1227.
Miller, T.L., 2004, Revised policy for the approval of U.S. Geological Survey (USGS) water-quality analytical methods: U.S. Geological Survey, Office of Water Quality Technical Memorandum 04.01, 5 p.

Routledge, E.J., and Sumpter, J.P., 1996, Estrogenic activity of surfactants and some of their degradation products assessed using a recombinant yeast screen: Environmental Toxicology and Chemistry, v. 15, no. 3, p. 241-248.

Teske, S.S., 2009, Aspects of measuring mass balances of endocrine disrupting compounds through wastewater treatment: Tucson, University of Arizona, Ph.D. Dissertation, 349 p., 107 figs., 16 tables.

U.S. Geological Survey, variously dated, National field manual for the collection of water-quality data: U.S. Geological Survey Techniques of Water-Resources Investigations, book 9, chaps. A1-A9, available online at http://pubs.water.usgs.gov/ twri9A

Vajda, A.M., Barber, L.B., Gray, J.L., Lopez, E.M., Woodling, J.D., and Norris, D.O., 2008, Reproductive disruption in fish downstream from an estrogenic wastewater effluent: Environmental Science and Technology, v. 42, no. 9, p. 3407-3414.

Wick, A., Fink, G., Joss, A., Siegrist, H., and Ternes, T.A., 2009, Fate of beta blockers and psycho-active drugs in conventional wastewater treatment: Water Research, v. 43, no. 4, p. 1060-1074.

Wilson, V.S., Bobseine, K., and Gray, Jr., L.E., 2004, Development and characterization of a cell line that stably expresses an estrogen-responsive luciferase reporter for the detection of estrogen receptor agonist and antagonists: Toxicological Sciences, v. 81, p. 69-77.

Woodling, J.D., Lopez, E.M., Maldonado, T.A., Norris, D.O., and Vajda., A.M., 2006, Intersex and other reproductive disruption of fish in wastewater effluent dominated Colorado streams: Comparative Biochemistry and PhysiologyC: Toxicology and Pharmacology, v. 144, no. 11, p. 10-15.

Zaugg, S.D., Smith, S.G., Schroeder, M.P., Barber, L.B., and Burkhardt, M.R., 2007, Methods of analysis by the U.S. Geological Survey National Water Quality Laboratory-Determination of wastewater compounds by polystyrene-divinylbenzene solid-phase extraction and capillary-column gas chromatography/mass spectrometry: U.S. Geological Survey Water-Resources Investigations Report 2001-4186, 37 p. 
Publishing support provided by:

Denver Publishing Service Center, Denver, Colorado

For more information concerning this publication, contact: National Water Quality Laboratory

Box 25585, Mail Stop 407

Denver, C0 80225-0585

(303) 236-2000

Or visit the National Water Quality Laboratory Web site at: http://nwql.usgs.gov/ 
